UDK: $364.633-212: 378.017(497.5)$

Preliminary communication

\title{
PREVENTION OF GENDER-BASED VIOLENCE AS HIGHER EDUCATION LEARNING OUTCOME: TEACHING, LEARNING AND ASSESSMENT OF HUMAN RIGHTS LEARNING OUTCOMES IN CROATIA
}

\author{
Marina Matešić \\ Ministry of Science and Education \\ Republic of Croatia \\ matesic2@yahoo.com \\ Ines Vrečlko \\ Doctoral Candidate \\ Faculty of Law, University of Ljubljana \\ Republic of Slovenia \\ inesvrec@yahoo.com
}




\section{ABSTRACT}

Teaching and learning about men's violence against women, domestic violence, interpersonal and sexual violence present a challenge to all higher education systems. Social responsibility, national and international legal frameworks on prevention and treatment of gender-based violence, as well as the demands of different professions that deal with victims, point to the complexity and necessity of delivering learning outcomes on gender-based violence, particularly those related to social skills and attitudes. Additionally, the global, national and institutional context, such as the oftenconfronted public actors and heated public forums on human rights violations and gender equality issues, influence higher education efforts to deliver human rights and gender equality learningoutcomes with students in ways that still need to be uncovered. The study presented in this article is based on a survey done with Croatian and Swedish health, social work and criminal justice study programmes, with particular focus on the prevalence and features of learning outcomes on gender-based violence. The analysis aims to investigate the influence of the socio-political and institutional context, attitudes and opinions of Croatian academic stakeholders on content and methods of teaching and assessment of students' knowledge, soft skills and attitudes about human rights and gender-based violence, compare them to Swedish results and frame them in a broader national and international discussion on the quality and responsibility of higher education.

Keywords: learning, assessment, higher education, human rights, gender-based violence, gender equality. 


\section{INTRODUCTION}

Higher education institutions today are more and more faced with needs to prepare students for future careers. Depending on their choice of career, some of the students will be facing sensitive human rights issues and violations, such as gender-based violence (GBV), violence against women and girls, sexual, partner and domestic violence. Scholarship on education on human rights as learning outcomes (LOs) supports the idea that different types of LOs besides knowledge are needed, such as social skills and attitudes. This reflects significantly on the need for the diversification of methods of teaching, learning and assessment. The necessity to acquire knowledge about human rights through or in addition to social skills, attitudes, and responsibilities, i.e. not as mere units of theoretical knowledge, usually about conventions and policy documents, is central to the teaching of human rights for any profession. For professions that entail direct contact with victims of violence or human rights violations who are traumatised, the diversity and appropriateness of methods in acquiring and assessing relevant LOs is even more important. This paper presents the results of a survey with representatives (directors, lecturers, and students) of study programmes in health and criminal justice in Croatia in order to map their views, attitudes and opinions on human rights and GBV as LOs of their study programmes. The survey inquired as to how stakeholders perceived GBV in relation to programme LOs, weather learning about it needed to increase or improve and what changes needed to take place. The article further analyses diversification of LOs and inclusion of those that develop students' social skills and attitudes. In that respect, two study programmes nominated by stakeholders are presented as examples of good practice in which GBV LOs were included appropriately both in terms of the extent of the content and in terms of LO diversification. In particular, the discussion to which we aim to contribute is the one on assuring quality of teaching, learning, and assessment by focusing beyond units of knowledge. Inquiring about challenges in teaching and learning skills, attitudes and values towards human rights and gender equality issues, this paper discusses in particular how dependent are these on the sociopolitical and institutional context, taking Croatia as a case study.

\section{GENDER-BASED VIOLENCE IN EDUCATION GLOBALLY AND LOGALLY}

Most professions require individuals to be prepared directly or indirectly to deal with human rights issues while some are explicitly involved in dealing with 
the consequences of gender-based and interpersonal violence. This is particularly so for health and criminal justice professions where professionals often come in contact with victims or perpetrators of violence. To be able to prepare students to help the victims of violence according to the proscribed professional and legal expectations (abiding to standards and guidelines) on the one hand and to support them in preserving their own physical and mental health as professionals who deal with violence on the other presents a challenge for institutions of higher education. Many international conventions recognise the importance of learning about human rights as well as the responsibility of higher education in contributing to this education. The Convention on the Elimination of all Forms of Discrimination Against Women (1979) opened up a new human rights avenue, joining issues of gender inequality, violence, and the need for education, which was further incorporated in the Declaration on the Elimination of Violence against Women (1993), the 4th World Conference on Women in Beijing (1995), and subsequent legislation in Europe. The Council of Europe concurred in this development and even led the way in human rights education development. ${ }^{1}$ Numerous action plans, programmes, and declarations have paid particular attention to higher education, recommending diverse methods of teaching and learning, interdisciplinarity, the training of teachers, and the participation of NGOs. In 2011, the Council of Europe passed the Convention on preventing and combating violence against women and domestic violence (also known as the Istanbul Convention), that in 2014 entered into force after being adopted by the majority of European countries. Finally, the Istanbul Convention merged the need for abiding and implementable international policy on combating GBV and developments in human rights education, as education plays a central role both in terms of professionals who deal with victims and in the general prevention and elimination of prejudices. According to the Istanbul Convention, members are to pay special attention to training professionals who deal with victims or perpetrators in order to prevent and detect such violence, uphold equality between women and men, protect the needs and rights of victims, as well as prevent secondary victimisation (art. 15). Members are also to "include teaching material on issues such as equality between women and men, non-stereotyped gender roles, mutual respect, non-violent conflict resolution in interpersonal relationships, gender-based violence against

1 Vienna Declaration and Programme of Action (1993), Final Declaration and Action Plan (1997), Declaration and Programme on Education for Democratic Citizenship, based on the Rights and Responsibilities of Citizens (1999), Declaration on Higher Education and Democratic Culture (2006), Recommendation of the Committee of Ministers to Member States on the Public Responsibility for Higher Education and Research (2006), and the Charter on Education for Democratic Citizenship and Human Rights Education (2010). 
women and the right to personal integrity, adapted to the evolving capacity of learners, in formal curricula and at all levels of education" (art. 14).

Croatia's development of human rights education has had a much shorter period of development then most European, particularly Northern European, countries, and has been faced with difficulties in the past quarter of the century. As a former socialist state that was struck by war, it shares numerous challenges in establishing human rights education. Due to its orientation to joining the European Union, democratic and human rights education become recognised as a goal, although not quickly implemented. The European Union and Council of Europe on the other hand recognised the need to support not only eastern, but also western countries in this endeavour after the fall of the Iron Curtain. Unlike somewhat novel concepts of citizenship and democracy that appeared in the period of transition to parliamentary democracy, gender equality for former Yugoslav countries was both an old and new issue. Socialist states invested immensely in the equality of women in terms of political engagements, education, social and labour status and welfare, and yet at the same time did very little in the field of education, prevention and sanctioning of GBV and inequality outside the work or political spheres.

The first specialized law on gender equality was passed in 2003, which outlined the areas of education as one of the foci (Gender equality act, 2003). Higher education and science were assigned the role of promoting constitutional values of gender equality, fighting discrimination based on gender, and creating equal opportunities for women and men. Higher education was to "promote gender studies educational programmes based on non-discriminatory knowledge about men and women" and "to eliminate sex and gender inequalities and gender stereotypes" (art. 14.). The law assigned all governmental and public institutions, especially educational ones, the responsibility to develop "systematic education and raising awareness on gender equality". Yet no implementation of the law was ever envisaged or enacted. Further developments of this law insignificantly developed the area of policy and action. All in all, neither have health education nor civic education ever entered the school curriculum, and not many goals were accomplished on the level of higher education besides basic gender and women studies courses (Barada et al 2003; Potkonjak et al, 2008; Prlenda, Sutlović, 2015).

Still, the discussions on human right, gender equality and democracy in education have mushroomed in the past 25 years, proving the topic to be of significant importance for both citizens and researchers (see e.g. Spajić-Vrkaš, 2000, 2003; Baranović, Ilišin, 2004; Matešić, Ivković Hodzić, 2019). Research on human rights content in higher education was quite scarce. Some research was conducted on attitudes of students of different professions to victims of violence 
and the LGBT population and showed that the higher education system has a long way to go in challenging stereotypes about, for instance, female rape victims or vulnerable population (KovčoVukadin, Vukosav, 2011, Lotar Rihtarić et al, 2012). Even more so, the research on attitudes of students to the LGBTIQ population found that police college students have stronger prejudices then students of other programmes (KovčoVukadin, 2015). Other researchers have pointed out the challenges of higher education to deal with gender- or sexuality-based prejudices as well as public policy in general when it comes to human rights training in Croatia. In her report on the introduction of human rights education in schools, Spajić-Vrkaš concludes $(2000,21)$ that any attempt to impose a nation-wide curriculum or policy without previous higher education training of professionals will fail in many ways if the ideological standpoints and cleavages between the 'conservatives' and the 'progressives' are not taken into account beforehand.

These, although scarce, findings are important for understanding why health education (which includessexeducation and prevention of GBV) and civiceducation (which includes gender and sexuality equality) became points of confrontation on national and institutional levels along progressive/conservative lines and why the introduction of human rights education into the school curriculum was postponed for more than five years. The conflict continued throughout the government's struggle to ratify the Istanbul Convention in 2018, against the wishes of part of its own members and civil initiatives, primarily because of the Istanbul Convention's educational elements. Similar and successful oppositions to ratification happened in Bulgaria, Romania, and Hungary. Although the resistance to the Convention temporarily faded out, gender equality and GBV as subjects of study remain severely charged topics of discussion. Therefore, both legal and social obligation of the HEIs to prepare their students for future professional expectations, acquiring knowledge and skills to recognise, treat and prevent human rights violations and GBV in the best possible way, cannot be entirely detached from personal attitudes, institutional culture and the broader socio-political context.

Furthermore, GBV is an important issue for higher education not only because of social responsibility and legal requirements and standards regulating certain professions dealing with victims of violence, but also because higher education institutions need to prepare students for future careers that include interpersonal skills in the most sensitive life situations such as the treatment of victims of sexual violence, children, and other particularly vulnerable groups. It is necessary for both the professional and theoretical/general educational content to include LOs beyond 'knowing' and 'understanding', and about 'doing' and 'having a feeling', i.e. having social skills and values that are crucial for students' future careers and 
wellbeing. For traditional higher education institutions, this often requires some rethinking of how units of learning are being taught, how students learn, and how knowledge, skills, and attitudes are assessed. This is not to say that the methods of teaching and assessment should not always be closely connected to the nature and the extent of necessary and relevant knowledge regardless of the topic. Still, teaching and learning about GBV more than most other units of learning in higher education necessarily requires that fundamental and theoretical units of knowledge be closely connected to applied skills (both professional and social) and standards of behaviour. Attitudes, social skills and factual knowledge, therefore, go hand in hand, and invested learning process will accomplish progress in all aspects. This was, after all, one of the strong foci of the aforementioned conventions.

Many European countries followed and some led the trend of setting out specific protocols for the treatment of victims by the police, justice system, medical and forensic professionals, therapists, and other related professions, which evidently focused on social skills of professionals. In Croatia, as in other European countries, protocols were developed for different types of crimes, e.g. protocols were developed for sexual violence, domestic violence, abuse and neglect of children, and violence among children and youth, victims of trafficking, treatment of refugees. These practical guidelines and rules for the treatment of victims, such as approach, providing support and interviewing the victims, should have quickly entered higher education programmes that prepare individuals for future careers in relevant professions. One such fundamental LO that is derived from these protocols is being able to interview the victim so that both professionalism and full support is provided. This includes complex sets of knowledge, social skills, and attitudes whereby, as stated in the Protocol for treatment of victims in cases of sexual violence (2018), the person interviewing a victim of sexual violence should:

- have attained previous special training on sexual violence

- recognise and take into account all relevant characteristics of the victim (age, physical and psychological state, the type and consequences of the crime committed), and

- accordingly adjust interviewing techniques, including expressing understanding and support, avoiding prejudices, forming trust, and choosing terminology appropriate to the victim's understanding.

These legal and professional expectations unquestionably influenced higher education institutions in their development and improvement of curricula. How, remains to be seen. 


\section{TEACHING AND LEARNING ABOUT GBV - METHODS AND GHALLENGES}

Regardless of how developed the national legislation, strategies, and policies on these aspects are, higher education is faced with a complex learning content that combines knowledge, skills, and attitudes as equally important aspects of LOs. This presents a challenge, predominantly in the aspects of skills and attitudes, for teaching, learning, evaluation, and assessment. Learning processes for such outcomes essentially need teaching methods such as learning by doing and competenciesbased learning, as well as emphasis on perceived relevance, value and belief in the usefulness of the learning material. Research on servicelearning is particularly vibrant and sometimes even referred to as a revolutionary pedagogical tool, pointing to its success in not only student satisfaction and achieving skills and attitudes, but also achieving fundamental knowledge through doing (Bringle, Hatcher, 1995; Jacoby, 1996; McKenna, Rizzo, 1999; Speck, Hope, 2004; Butin,2005; Lemieux, Allen, 2007, Lin, Moore, 2009, Deeley, 2014, Enos, 2015, Harrop-Allin, 2017, Pacho, 2018, Traver, Katz, 2018). Studies have shown that service learning in shelters for battered women seems particularly effective in achieving social skills Los, but also explores avenues for the teacher in the assessment of student participation (Mikolchak, 2006). In other examples, 'immersion' as a learning method for assessment and intervention in domestic violence proved to be very effective in nursing programmes (Davila, 2005). Simulated learning such as games and role-playing, furthermore, seem to be more affordable and easier to organise at universities and very useful for both communication skills and attitudes (Lane, Rollnick, 2007).

Secondly, teaching human rights in general presents a challenge with regards to respecting and evaluating different opinions and students' personal attitudes, including the dilemma as to whether personal attitudes and sensibilities of students should be formally assessed at all. Scholarship on the assessment of social skills, values, and attitudes is diverse and ranges between underlining the need to find a proper assessment method (if it is not assessed, why learn it) and restraining from assessment of such LOs altogether. For instance, many of the scholars on service learning propose distancing from traditional assessment, such as focusing on the evaluation of the learning process instead of assessment based on already determined goals or evaluation through observational methods that do not include judgment or criticism (Mikolchak, 2006), or even self-evaluation (or peer-evaluation) of students as a method of self-assessment (or peer-assessment) that teaches students long-term skills beyond the course and education (Boud, Soler, 2015). All this points to a shift in paradigm from teaching and assessment 
to learning (Barr, Tagg, 1995) and from assessment of learning to assessment for learning (Brown, 2005). Therefore, central to what and how to learn about GBV lies the question of methods of and assessment learning. The analysis of survey with representative of heath and criminal justice study programmes presented here aims to screen not only the extent of study content on GBV but also the methods of teaching and the assessment of learning about it.

\section{METHODOLOGY}

The paper presents the results of a survey conducted with heath and criminal justice study programmes in Croatia with comparative reflections on research results within the international project Modernity, Human Rights and Education. In this project, partner countries, Sweden, Portugal, and Croatia, set a goal of investigating how three different human rights LOs are included in targeted study programmes that prepare students for future careers dealing with particular human rights issues: 1) GBV, 2) migration, citizenship, and inter-culturalism, 3) citizenship education and children's participation. Croatian and Swedish research teams specifically set head to investigate the extent, the features and the context of GBV as LO of surveyed study programmes. Sweden and Croatia were using the same questionnaire to enable comparison, although there were smaller differences in targeted programmes, as in each country they prepare for slightly different professions. The article presents the results of the Croatian survey analysis and compares them to Swedish results. Furthermore, the study includes the content analysis of study programmes nominated as examples of good practice as a part of a case study approach.

The survey was distributed to all of the health, social work and criminal investigation (criminalistics) programmes which train for 9 different qualifications (doctor of medicine, BA and MA in nursing and occupational therapy, social work and criminal investigation) at 13 different higher education institutions, in total 53 programmes. The response rate was around $50 \%$ or 26 responses. Some programmes were represented with more than one response, as the instructions were given that responses should be provided by study directors, lecturers, and students. With only two student responses, the rest of the responses were submitted by directors (9) and lecturers (15). Although reciprocally distributed through disciplines, the overall small number of some study programme (social work and criminal investigation) responses was too low to make conclusions with specific discipline analysis, but valuable in terms of mapping content, methods and tools used, as well as attitudes and awareness of respondents about available educational methods. 
Table 1. Survey response

\begin{tabular}{lcc}
\hline Study programme qualification & No. of institutions & No. of responses \\
\hline Doctor of Medicine & 4 & 6 \\
\hline Bachelor of Occupation Therapy & 1 & 1 \\
\hline Master of Occupation Therapy & 1 & 1 \\
\hline Bachelor of Nursing & 6 & 12 \\
\hline Master of Nursing & 2 & 2 \\
\hline Bachelor of Criminal Investigation & 1 & 2 \\
\hline Master of Social Work & 2 & 2 \\
\hline
\end{tabular}

Finally, some respondents stated that they consider their programme to be an example of good practice, some indicated that changes in study programmes were going to be made in the near future and some respondents stated that new programmes were going to be created which would be aligned more costly with human rights violation standards discussed here (conventions, protocols and other legal and policy requirements). These examples were looked into in more detail in reflection to survey fields of analysis.

\section{ANALYSIS OF THE RESULTS}

The assessment of GBV LOs violence in higher education programmes was first conducted in Sweden in 2016-2017, and the same survey and research design was replicated in Croatia in 2018-2019, with the exception of the Croatian case including also the programmes in criminal investigation (preparation for future careers in law enforcement and the criminal justice system). Sweden is often considered to be one of the most developed systems of education in general, particularly in terms of human rights, women's rights, and tackling GBV, which among other policy measures are proscribed by legal provisions regulating medical and other professions as mandatory learning targets. Still, the survey conducted in Sweden with medical and social welfare study programmes on LOs in education on human rights, men's violence against women and domestic violence, and violence against children showed some areas for improvements. Although legal requirements proscribe that study programmes should include the said LOs, and the representatives of the programmes confirmed the overall presence of such LOs in the curricula (in $96 \%$ for human rights, $82 \%$ for GBV, and $88 \%$ for violence towards children), the respondents also reported a much lower inclusion of these LOs as explicit programme LOs (Tegler Jerselius et al, 2017,16,19). This was particularly 
so in relation to the topic of men's violence against women and domestic violence (41\%) and similarly so for violence against children (48\%). While programmes in medicine have over $80 \%$ of such LOs (all three topics), only a bit more than one third of nursing as well as social work and occupational therapy programmes had LOs that relate to knowledge of GBV (37\%) (20). Further findings in the report state that LOs on GBV and violence against children are underrepresented in all aspects of the programme content, for example in respect to teaching about the area which seems to be less formalised, or in fact that only half of the respondents stated they were included in mandatory literature (22). Teaching methods reported as used were quite diverse, ranging from lectures and seminars (65-90\%) to group work (40-70\%), self-study (50-60\%), individual work/written tasks (30-50\%), and placements and supervision (30-40\%) (26). Examination was present in a majority of the cases (over $85 \%$ ), usually through seminars and oral presentations (60\% for the topic of GBV), half used written exams, and less than a third used essays and independent projects (12). Finally, when asked about changes to the programme, only around 30\% answered in the affirmative regarding all three topics (37). The overall conclusions of the authors are that compared to the responses for human rights, the other two areas, those of men's violence against women and domestic violence, and violence towards children "is less prominent and where it does take place, it is less formalised" (42.). The authors further conclude that there is also "a greater disparity among the respondents about whether legal requirements necessitate inclusion of the two areas in the curricula".

The survey results in Croatia align with some of the above mentioned Swedish results, but nevertheless show differences. The same standardised questionnaire was distributed to selected and qualified study programme holders, which then was in a majority of the cases, filled in by programme directors or teachers in charge, but while in Sweden the respondents participated under their full name and position, in Croatia there was a strong presence of anonymous responses (almost one third). ${ }^{2}$ As discussed before, and due to a preceding public debate on the Istanbul Convention adoption, some the respondents expressed their fears about the sensitivity of the topic openly, referring to the convention and protests against it, while others remained anonymous for reasons unknown to researchers.

The most important findings in the Croatian survey were as follows. Although slightly less than in Sweden, a majority of the respondents answered affirmatively when asked whether the programme included teaching on the topics: $80 \%$ confirmed teaching about human rights, $63 \%$ responded affirmatively about

2 One of the demands from the respondents was to modify the questionnaire in order to assure its anonymity, while others, even managerial positions expressed concern about speaking out loud about the 'Istanbul Convention related survey'. 
GBV, while 71\% confirmed the inclusion of LOs about violence towards children. Unlike the Swedish survey, the majority of Croatian respondents also responded positively on the inclusion of topic-specific LOs as programme LOs. For instance, $83 \%$ responded affirmatively on the inclusion of human rights, $80 \%$ on GBV and $82 \%$ on violence towards children. Unlike the Swedish case, there were no visible differences among disciplines of the programmes in responses. Like in Sweden, almost all the respondents stated that the inclusion of human rights LOs into the programme content was a legal requirement. This was an interesting finding as there are no legal requirements that would proscribe the content or set learning targets as there are in Sweden. It is important to note that the legal framework of higher education and quality assurance system in Croatia do not require study programmes to state LOs on the level of programme, which means that the responses in this section of the questionnaire were individual impression or assessments of the respondents. As one of the respondents stated, "learning outcomes are only defined on the level of courses, and not on the level of a topic, so it is difficult to determine programme learning outcomes on any specific topic as they overlap throughout different courses".

Taken as an impression of the respondents, still the inclusion of LOs about GBV was significantly lower than the other topics. Some of the respondents whose answers were not inclusive of the topic of men's violence against women stated that such topic was not part of the curriculum because the curriculum deals with "exact and experimental science", because the "courses are professional" (aiming only at future professional skills), because the curriculum was "overcrowded as it is, so only violence against children was included" or because "the national curriculum for nursing does not prescribe it".

When listing which LOs programmes relate to the topics of human rights and GBV, the respondents mostly stated knowledge-based units, such as 'knowing' or 'learning,' 'remembering' or 'repeating, 'describing', 'defining' and 'applying' the basic legal concepts of human rights and protocols for detecting abuse and treatment of victims. Only a small number of respondents stated LOs such as 'respect for', 'protecting and promoting', 'taking initiative, 'developing attitudes' or 'having a feeling' about human rights issues and abuses. These statements point to the overall systemic fact that most of the Croatian (higher) education curricula is based on knowledge units, while attaining attitudes and social skills are often seen as extracurricular and voluntary activities. For instance, in open-ended questions about the inclusion of LOs, many respondents explained that such LOs were not always achieved through the programme content only. Often they are offered through different university services such as counselling centres that provide not only 
guidance, but also training of such kind for students to join outside of the official programme curriculum.

When asked whether such LOs were represented in specific courses dedicated solely to human rights issues and whether they were mandatory, a majority responded in favour of integrated content or if appearing as a separate course, then elective. All but one responded positively on the inclusion of the specific LOs stated, and said LOs were a part of mandatory courses on broader topics included in obligatory literature. The respondents further rated the inclusion of the topics in the curriculum on a scale from 1 to 6 (the extent of inclusion, in which 6 was fully included). They rated the inclusion of teaching on human rights and violence against children with 4.5 on average both in theoretical/overall level and in practical understanding and the inclusion of teaching on GBV with 4.2 confirming lower inclusion of the GBV topic.

Teaching and learning methods that the respondents listed as being used seem diverse although all of the responses included traditional lectures, most included seminar work, some included practical experience, individual study of students with literature, and to a lesser extent (around 20\%) group assignments. Teaching competencies of the staff giving courses in human rights-related LOs were also diverse, but primarily formal qualifications such as completed programme in the relevant field or research on the topics. Less common were responses stating teachers with first-hand experience on the topic as qualification. Similarly, the assessment methods, although diverse, were dominantly traditional and formal assessment such as written exam administered at the end, or consecutively. In that sense, the responses in this section slightly differ from those given in the Swedish survey.

Concerning the final set of questions, a small number of respondents expressed plans for improvements, which was also another similarity to Swedish results. Namely, only $1 / 4$ of the respondents stated that they planned to make changes with respect to developing LOs in human rights, and $1 / 3$ of them planned changes in terms of education about men's violence against women and domestic violence, as well as about violence toward children. Those that planned further development, such as the introduction of new elective courses (which was the most common response), were predominantly students of nursing (none of the medical doctor programmes have plans for improvement) which already do have courses and content in the topic, while those that did not, in general, did not express any plans for change. Some stated that changes in the curriculum of the programme were hard to achieve, while others stated courses and training could be introduced as extra-curricular activities. Those stating a need for improvements gave very few answers explicitly stating any improvements in 
terms of GBV, while improvements stating the protection of children were more commonly expressed.

The respondents were further asked whether they considered their programme to be an example of good practice, and respondents from six different programmes confirmed (one in medicine, one in criminal investigation and the rest in nursing). These respondents declared to have programme and subject LOs covering GBV, that these were a part of obligatory contents, mandatory study materials, and that they were formally assessed by field-specific and competent lecturers. All except one declared not to plan any changes in the programme. However, looking more closely at their responses to earlier questions, none of the programmes stated to have explicit subjects on GBV or violence against women. All of them reported having GBV as integrated content in other courses. Two of the respondents considered their programmes as good practice examples (one in medicine and one in nursing) and stated to have no content at all on GBV. Some nursing programmes had courses in violence against children, criminal investigation programme response included a course on minor delinquency as inclusive of LOs on violence against children, but other respondents mentioned generic fields of study, such as ethics, social medicine, paediatrics, or clinical diagnostics.

\section{FOLLOW-UP ON EXAMPLES OF GOOD PRACTICE}

In the follow-up period of the project when results of the survey were presented, two institutions reported improvements in this regard. The Croatian Catholic University created and successfully accredited a new six-year programme in medicine which, as reported by the programme director, includes LOs in three different modules, among which the module of medical humanities stands out as a possible example of good practice. The second example are the BA and MA programmes in Criminal Investigation that report changes in the curricula and extracurricular content which, besides violence against children, now include explicit LOs and courses on gender-based and domestic violence. Plans for establishing student volunteering programmes have been set in motion with a goal of becoming a part of the obligatory content. The programme aims to utilize service learning in order for students to achieve knowledge, social skills and values through doing and in relations to vulnerable social groups.

The new medical doctor training programme in particular presents an interesting innovation for traditional Croatian medical training, as the programme is designed in modules as pillars of the programme that last throughout its duration. Some of the modules that deal with GBV are Skills of the Doctor, Medicine in the 
Community, and particularly Medical Humanities. While Skills module serves the purpose of providing training for building skills, it also states it supports the formation of attitudes relevant for recognising and treating GBV. Some of the content topics in which these LOs are achieved are those about the first contact with patients and social propaedeutics (working with particularly vulnerable groups). Besides traditional theoretical and practical teaching and learning methods, there is also a mention of service learning and volunteering organised by the institutions as integral part of the training. Medicine in the Community further encompasses topics of social context to heath, such as family, social and global conditions which are marked by inequalities in access to health and health services. Finally, the Medical Humanities module, although it might seem as an elective branch of the programme, is a very much obligatory and core content to medical training and clearly represented in programme LOs. Humanistic and innovative aspects of the programme are put at the forefront of the programme mission, as training competent doctors necessarily includes patient-cantered medicine and social accountability. The elaboration of the humanities module further explicitly states how, unlike other medical training programmes, this programme will clearly send value-based messages, such as about detriments of domestic violence. The module includes knowledge, values and attitudes about key patient and human rights and violations, including knowledge about different international conventions, policy recommendations and protocols, particularly in terms of roles, duties and moral values delegated to medical professionals.

\section{CONCLUSION}

Survey results confirm that a majority of the programmes are aware of the general, theoretical and legal responsibility to train future professionals in these topics and some are also aware of the social responsibility to do so. Almost one third of the respondents decided to remain anonymous and this might point to the broader socio-political context burdened by the heated and confronted public debate on the adoption of the Istanbul Convention at the time of the survey. Still, most of the respondents assessed their programme as offering teaching on said topics, and the majority is aware that such LOs are important. Although most of the responses declare to have programme and subject LOs covering human rights or violence against children, that these are a part of obligatory content, mandatory study material, and that they are formally assessed by field-specific and competent lecturers, none of the programmes state they have explicit subjects on GBV or violence against women. They report having GBV as integrated content 
in other courses. Two of the programmes respondents that consider themselves good practice examples (one in medicine and one in nursing) state they have no content at all on GBV. Some nursing programmes state courses in violence against children, and criminal investigation programme response includes a course on minor delinquency as inclusive of LOs on violence against children, but other respondents mention generic fields of study, such as ethics, social medicine, or core clinical subjects. This indicates there is space for improvement although some examples of good practice exist, both in terms of how they include GBV in the curricula (inclusion of the topic in several constituent modules throughout the curricula or inclusion of explicit courses dedicated to domestic and GBV) and outside of HE institution and its curricula (volunteering, practical assignments explicitly aiming at knowledge, skills and values in GBV). Therefore, although most of health, criminal justice and social work professions require future professionals to be prepared to deal with consequences of gender-based and domestic violence, the study shows there is still a long way to go. Hopefully, this study, together with some examples it brings can be useful in moving along that way. 


\section{REFERENCES}

1. Barada, V., Janušić, J., Kašić, B., Pešut, J. (2003). Institucionalizacija ženskih studija - akcijsko istraživanje. Zagreb: Centar za ženske studije.

2. Baranović, B., Ilišin, V. (2004). Mladi i ljudska prava u Hrvatskoj. Sociologija i prostor: časopis za istraživanje prostornoga i sociokulturnog razvoja, 42(3/4): 339-361.

3. Barr, R. B., Tagg, J. (1995). From Teaching to Learning: A New Paradigm for Undergraduate Education. Change: The Magazine of Higher Learning, 27(6): 12-26, doi:10.1080/00091383.1995. 10544672.

4. Boud, D., Soler, R. (2015). Sustainable assessment revisited. Assessment and Evaluation in Higher Education, 41(3): 400-413, doi: 10.1080/02602938.2015.1018133.

5. Bringle, R., Hatcher, J. A. (1995). A Service-Learning Curriculum for Faculty. Michigan Journal of Community Service Learning, 2(1): 112-122.

6. Brown, S. (2005). Assessment for Learning. Learning and Teaching in Higher Education, 1: 81-89.

7. Butin, D. (2005). Service learning in Higher Education: Critical Issues and Direction. USA, Springer.

8. Davila, Y. R. (2005). Teaching Nursing Students to Assess and Intervene for Domestic Violence. International Journal of Nursing Education Scholarship 2(1), doi: 10.2202/1548-923x.1076.

9. Deeley, J. (2014). Critical Perspectives on Service Learning in Higher Education, USA, Springer.

10. Enos, S. L. (2015). Service Learning and Social Entrepreneurship in Higher Education: A Pedagogy of Social Change. USA, Pelgrave Macmillan.

11. Harrop-Allin, S. (2017). Higher Education Student Learning beyond the Classroom: Findings from a community music service learning project in rural South Africa. Music Education Research, 19(3): 231-251.

12. Hutchings, P., Wutzdorff, A. (1988). Experiential learning across the curriculum: Assumptions and principles. New Directions for Teaching and Learning, 35: 5 - 19.

13. Jacoby, B. (1996). Service-learning in higher education: concepts and practices. San Francisco, CA, USA, Jossey-Bass Publishers.

14. Kovčo Vukadin, I., Vukosav, J. (2011). Students' Attitudes towards Risk, Victimization and Punishment in Croatia. In H. Kury, E. Shea (Eds.), Punitivity - International Developments (pp. 379-399). Bochum, Germany: Universitaetsverlag Dr. Brockmeyer.

15. Kovčo Vukadin, I. (2015). Stavovi studenata Visoke policijske škole o osobama homoseksualne orijentacije. Kriminologija i socijalna integracija, 23(2): 173-212.

16. Lane, C., Rollnick, S. (2007). The use of simulated patients and role-play in communication skills training: a review of the literature to August 2005. Patient Educ. Couns., 67(1-2): 13-20, doi: 10.1016/j.pec.2007.02.011.

17. Lemieux, C. M., Allen P. C. (2007). Service learning in social work education: the state of knowledge, pedagogical practicalities, and practice conundrums. Journal of Social Work Education,43:2:309-326, doi: 10.5175/JSWE.2007.200500548.

18. Lin, L. P., Moore M. (eds) (2009). Service-Learning in Higher Education: Paradigms and Challenges. USA, University of Indianapolis Press. 
19. Lotar Rihtarić, M., Jaček, J., Kovčo Vukadin, I. (2012). Students' stereotypes about female victims. In: M. Milković, D. Doležal, G. Hržica, J. Stošić (eds.) Knjiga sažetaka 8. međunarodnog znanstvenog skupa - Zagreb, Knjiga 22, (pp 315-316), Zagreb: Edukacijsko-rehabilitacijski fakultet, Sveučilišta u Zagrebu.

20. Matešić, M., Ivković Hodžić, Ž. (2019). Human Rights Learning Outcomes in Higher Education: Assessing Learning Outcomes in Human Rights, Children's Rights and Participation and Active Citizenship. Zagreb, Croatia: AZVO.

21. McKenna, M. W., Rizzo, E. (1999). Student Perceptions of the "Learning” in Service-Learning Courses. Journal of Prevention and Intervention in the Community, 18(1-2): 111-123, doi: 10.1300/J005v18n01_09.

22. Mikolchak, M. (2006). Service Learning in English Composition: A Case Study. Journal of Scholarship of Teaching and Learning, 6(2): 93-100.

23. Pacho, O. T. (2018). Service-Learning in Higher Education in Africa. UK, Cambridge Scholars Press.

24. Potkonjak, S., Arsenijević, D., Demiragić, A., Petrović, J. (2008). Između politike pokreta i politike znanja: feminizam i ženski/rodni studiji u Hrvatskoj, Bosni i Hercegovini i Sloveniji. Studia ethnologica Croatica, 20(1): 57-96.

25. Prlenda S., Sutlović, L. (eds.) (2015). Pathways of Education for Gender Equality Research Report on the project Gender Equality, Unemployment and Lifelong Learning in Europe - Impact on Life Chances of Young Women. Zagreb, Croatia: Centre for Women's Studies.

26. Protokol o postupanju u slučaju seksualnog nasilja (Protocol for treatment of victims in cases of sexual violence) (2018). Official Gazette 70.

27. Spajić-Vrkaš, V. (2000). Peace and Human Rights for Croatian Primary Schools. Zagreb, Croatia: Croatian Commission for UNESCO.

28. Spajić-Vrkaš, V. (2003). Visions, provisions and reality: Political changes and education for democratic citizenship in Croatia. Cambridge Journal of Education, 33(1): 33-51.

29. Speck, B. W. Speck, Hoppe, S. L. (2004). Service-learning: History, Theory, and Issues. Westport CT, USA, Greenwood Publishing Group.

30. Tegler Jerselius, C., Helldahl, P., Moberg R. (2017). A gender perspective on human rights education: assessing learning outcomes in higher education on human rights; men's violence against women, domestic violence and violence towards children in programmes in medicine and in social welfare. Stockholm, Sweden: UKA.

31. Traver, A., Katz, Z. (2018). Service-Learning as the American Community College: Theoretical and Empirical Perspectives. USA, Pelgrave Macmillan.

32. Vidačak, I., Spajić-Vrkaš, V., Božić, J. (2000). Obrazovanje za ljudska prava i demokraciju: Međunarodni adresar. Zagreb, Croatia: Croatian Commission for UNESCO.

33. Zakon o ravnopravnosti spolova (Gender equality act) (2003). Official Gazette 116. 


\section{PREVENCIJA RODNO UVJETOVANOG NASILJA KAO ISHOD UČENJA U VISOKOM OBRAZOVANJU: POUČAVANJE, UČENJE I VREDNOVANJE ISHODA UČENJA O LJUDSKIM PRAVIMA U HRVATSKOJ}

\section{SAŽETAK}

Poučavanje i učenje o muškom nasilju nad ženama i djevojčicama, obiteljskom nasilju, seksualnom $i$ partnerskom nasilju izazovna je tema za sve sustave visokoga obrazovanja. Društvena odgovornost visokoga obrazovanja, nacionalni i medunarodni pravno-politički okviri i strategije borbe protiv rodno uvjetovanoga nasilja, kao i zahtjevi raznih profesija koje svakodnevno pružaju podršku žrtvama, ukazuju na kompleksnost, ali i neizostavnu potrebu ostvarivanja ishoda učenja o rodno uvjetovanom nasilju, posebice onih koje svrstavamo u društvene vještine, stavove i odgovornosti. Pritom, globalni, nacionalni i institucionalni kontekst koji je često obilježen konfrontiranim stavovima $i$ uzavrelom atmosferom javne rasprave o temama kršenja ljudskih prava i rodne ravnopravnosti, izuzetno je važan čimbenik utjecaja na institucije visokoga obrazovanja u njihovim naporima da isporuče ishode učenja o ljudskim pravima i rodnoj ravnopravnosti. Istraživanje predstavljeno u ovom članku temelji se na anketi provedenoj u Hrvatskoj i Švedskoj spredstavnicima visokih učilišta koja izvode studijske programe u zdravstvu, socijalnom radu i kriminalistici. Anketni upitnik ispitivao je stavove voditelja programa, nastavnika $i$ studenata o zastupljenosti i odlikama ishoda učenja o ljudskim pravima i rodno uvjetovanom nasilju. Analiza rezultata imala je cilj mapiranje izjava, stavova i mišljenja dionika o zastupljenosti i vrsti navedenih ishoda, metoda poučavanja, učenja $i$ vrednovanja, uspoređujući ih pritom s rezultatima švedskoga istraživanja te stavljajući ih u širi društveno-politički kontekst.

Ključne riječi: poučavanje, učenje, visoko obrazovanje, ljudska prava, rodno uvjetovano nasilje, rodna ravnopravnost. 